\title{
Predicting and monitoring the effects of large-scale ocean iron fertilization on marine trace gas emissions
}

\author{
C. S. Law* \\ National Institute of Water and Atmospheric Research (NIWA), Evans Bay Parade, Private Bag 14-901, Kilbirnie, Wellington 6241, \\ New Zealand
}

\begin{abstract}
Large-scale ( $>40000 \mathrm{~km}^{2},>1 \mathrm{yr}$ ) ocean iron fertilization (OIF) is being considered as an option for mitigating the increase in atmospheric $\mathrm{CO}_{2}$ concentrations. However OIF will influence trace gas production and atmospheric emissions, with consequences over broad temporal and spatial scales. To illustrate this, the response of nitrous oxide $\left(\mathrm{N}_{2} \mathrm{O}\right)$ and dimethylsulphide (DMS) in the mesoscale iron addition experiments (FeAXs) and model scenarios of large-scale OIF are examined. FeAXs have shown negligible to minor increases in $\mathrm{N}_{2} \mathrm{O}$ production, whereas models of long-term OIF suggest significant $\mathrm{N}_{2} \mathrm{O}$ production with the potential to offset the benefit gained by iron-mediated increases in $\mathrm{CO}_{2}$ uptake. $\mathrm{N}_{2} \mathrm{O}$ production and emission will be influenced by the magnitude and rate of vertical particle export, and along-isopycnal $\mathrm{N}_{2} \mathrm{O}$ transport will necessitate monitoring over large spatial scales. The $\mathrm{N}_{2} \mathrm{O}-\mathrm{O}_{2}$ relationship provides a monitoring option using oxygen as a proxy, with spatial coverage by Argo and glider-mounted oxygen optodes. Although the initial FeAXs exhibited similar increases (1.5- to 1.6-fold) in DMS, a subsequent sub-arctic Pacific experiment observed DMS consumption relative to unfertilized waters, highlighting regional variability as a complicating factor when predicting the effects of large-scale OIF. DMS cycling and its influence on atmospheric composition may be studied using naturally occurring blooms and be constrained prior to OIF by prefertilization spatial mapping and aerial sampling using new technologies. As trace gases may have positive or negative synergistic effects on atmospheric chemistry and climate forcing, the net effect of altered trace gas emissions needs to be considered in both models and monitoring of large-scale OIF.
\end{abstract}

KEY WORDS: Iron fertilization $\cdot$ Trace gases $\cdot$ Nitrous oxide $\cdot$ Dimethlysulphide $\cdot$ Remineralization

\section{INTRODUCTION}

Enhancing ocean productivity and vertical carbon export by increasing iron supply will indirectly influence the production of a range of trace gases, often via a complex web of biogeochemical interactions. The resulting change in oceanic emissions may alter atmospheric composition with positive or negative feedbacks on radiative forcing, tropospheric oxidation capacity and ozone concentration (Liss et al. 2005). However, the response of oceanic trace gas emissions to iron fertilization is currently uncertain, primarily as indirect effects and biogeochemical feedbacks have received limited attention in the 12 mesoscale iron addition experiments (FeAXs) to date (Boyd et al. 2007). This is a reflection of the priority of FeAXs to test the 'iron hypothesis' (Martin 1990) by focussing on phytoplankton productivity and carbon export and of the relatively short-term nature and scale of FeAXs relative to the temporal and spatial scales of trace-gas cycling. For example, dimethylsulphide (DMS), non-methane hydrocarbons and halocarbons are influenced during the phytoplankton growth phase and generally show a short-term response in the surface mixed layer within days to weeks; conversely, production of trace gases that are influenced by remineralization of sinking particulate matter during the bloom decline and export phase occurs over greater temporal and spatial scales (Fig. 1). With the current consideration of large-scale ocean iron fertilization (OIF) (here defined as continuous fertilization over areas $>40000 \mathrm{~km}^{2}$ for periods of $>1 \mathrm{yr}$ ) as a strategy for lowering atmospheric $\mathrm{CO}_{2}$, there is a need to consider potential trace-gas responses, using FeAX observations, natural analogues and model scenarios, for pre- 
a
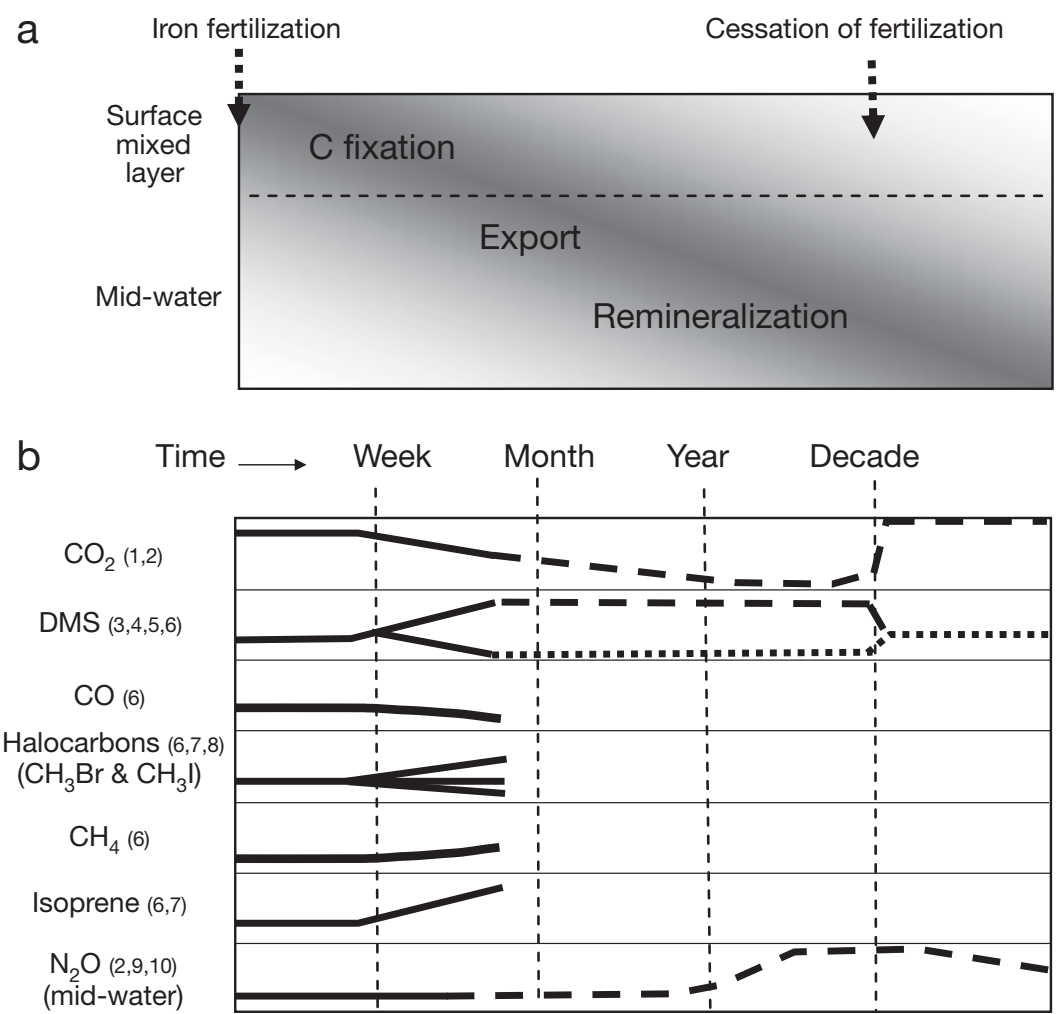

Fig. 1. (a) Conceptual response to iron fertilization showing the temporal evolution from carbon fixation during the bloom phase to remineralization in the midwater column, with cessation of iron fertilization after $10 \mathrm{yr}$. (b) Temporal response of $\mathrm{CO}_{2}$ and trace gases in surface waters and $\mathrm{N}_{2} \mathrm{O}$ in the mid-water column based on the FeAX observations (solid lines) and model output and extrapolations (dashed and dotted lines) of (1) Wong et al. (2006), (2) Jin \& Gruber (2003), (3) Turner et al. (2004), (4) Takeda \& Tsuda (2005), (5) Levasseur et al. (2006) (observed DMS results extrapolated as dotted line), (6) Wingenter et al. (2004) (observed DMS results extrapolated as dashed line), (7) Moore \& Wang (2006), (8) Liss et al. (2005), (9) Law \& Ling (2001), and (10) Walter et al. (2005)

diction and development of monitoring strategies (London Convention 2007).

\section{$\mathrm{N}_{2} \mathrm{O}$ RESPONSE TO OIF}

Nitrous oxide $\left(\mathrm{N}_{2} \mathrm{O}\right)$ is an example of a trace gas that may respond to OIF on greater temporal and spatial scales. The oceans are a major contributor to the global $\mathrm{N}_{2} \mathrm{O}$ budget, providing 5.6 to $14 \mathrm{Tg} \mathrm{Nyr}^{-1}$ (Bange 2006) of the total 7.6 to $41 \mathrm{Tg} \mathrm{Nyr}^{-1}$ (IPCC 2007), primarily from coastal, shelf and upwelling regions. Nitrification is the main source of $\mathrm{N}_{2} \mathrm{O}$ in the open ocean, with the yield increasing with decreasing oxygen (Goreau et al. 1980), as evidenced by an anti-correlation between dissolved $\mathrm{N}_{2} \mathrm{O}$ and oxygen throughout the oceans (Nevison et al. 2003). A $\mathrm{N}_{2} \mathrm{O}$ maximum in intermediate waters is apparent throughout much of the ocean; this maximum shoals and intensifies in upwelling regions, which act as 'natural chimneys' by contributing dispro- portionately to total marine $\mathrm{N}_{2} \mathrm{O}$ emissions (Law \& Owens 1990). Upwelling systems may be regarded as natural large-scale OIF analogues as they are characterized by enhanced vertical particle export. Elevated mid-water remineralization and oxygen consumption not only supports $\mathrm{N}_{2} \mathrm{O}$ production but also leads to anoxia, as observed in the Californian and Namibian coastal upwelling systems (Monteiro et al. 2006, Chan et al. 2008). Denitrification is a minor source but the primary microbial sink for $\mathrm{N}_{2} \mathrm{O}$ and occurs in anoxic sediments and water bodies. As surface and most intermediate waters do not experience hypoxia or contact sediments, $\mathrm{N}_{2} \mathrm{O}$ loss to denitrification will be minimal, so the ultimate fate of this $\mathrm{N}_{2} \mathrm{O}$ is ventilation to the atmosphere. $\mathrm{N}_{2} \mathrm{O}$ is relatively long-lived in the atmosphere and has a global warming potential (GWP) 310 times that of $\mathrm{CO}_{2}$ (Forster et al. 2007). The potential then exists for $\mathrm{N}_{2} \mathrm{O}$ emissions to offset the radiative decrease achieved by iron-mediated phytoplankton $\mathrm{CO}_{2}$ uptake and consequently monitoring and verification of $\mathrm{N}_{2} \mathrm{O}$ response should be a priority in any large-scale OIF.

Upscaling of observations from FeAXs to large-scale OIF is limited by the paucity of $\mathrm{N}_{2} \mathrm{O}$ measurements to date. No significant increase in mixed layer $\mathrm{N}_{2} \mathrm{O}$ concentration and emissions was observed on 2 Southern Ocean FeAXs (Law \& Ling 2001, Walter et al. 2005); however, an increase in $\mathrm{N}_{2} \mathrm{O}$ saturation of $7 \%$ was identified in the upper pycnocline in the Southern Ocean Iron Release Experiment (SOIREE) iron patch that co-varied with columnintegrated chlorophyll $a_{1}$ suggesting iron-induced stimulation of $\mathrm{N}_{2} \mathrm{O}$ production (Law \& Ling 2001). Excess $\mathrm{N}_{2} \mathrm{O}$ was not observed during a subsequent FeAX in the Southern Ocean, the European Iron Fertilization Experiments (EIFEX), although water column sampling was limited and did not focus upon density discontinuities where particles may accumulate (Walter et al. 2005). Measurements during the initial $13 \mathrm{~d}$ of the Sub-arctic Ecosystem Response to Iron Enrichment Study (SERIES) FeAX in the Gulf of Alaska identified an increase in $\mathrm{N}_{2} \mathrm{O}$ saturation of $8 \%$ at 30 to $50 \mathrm{~m}$ (C. Law unpubl. data) - coincident with increases in ammonium and nitrite - suggesting, but not confirming, nitrification as the source. Nitrification in the lower euphotic zone is a significant $\mathrm{N}_{2} \mathrm{O}$ source, contributing 
40 to $75 \%$ of atmospheric emissions from the sub-tropical gyres (Dore et al. 1998, Popp et al. 2002). Although generally considered insignificant in surface waters due to light inhibition, nitrification rates have recently been shown to be uniform throughout the surface mixed layer (Yool et al. 2007). These observations indicate the potential for local $\mathrm{N}_{2} \mathrm{O}$ production in surface waters - and hence atmospheric emissions - to increase following OIF on short timescales.

$\mathrm{N}_{2} \mathrm{O}$ production is not confined to surface waters, with the rate of vertical particle export determining the subsequent timeframe, magnitude and location of $\mathrm{N}_{2} \mathrm{O}$ emissions. Although few FeAXs have been of sufficient duration to record the export phase (Boyd et al. 2007), those that were, provide a range of findings. Vertical export below the thermocline was relatively insignificant during SERIES due to bacterial remineralization of the diatom bloom in near-surface waters (Boyd et al. 2005), whereas vertical export of a diatom bloom during EIFEX was rapid, with aggregate sinking rates of several hundred $\mathrm{m} \mathrm{d}^{-1}$ (V. Smetacek pers. comm.). This rapid export to the seafloor may account for the reported absence of $\mathrm{N}_{2} \mathrm{O}$ accumulation below the EIFEX patch (Walter et al. 2005), although the higher and more variable $\mathrm{N}_{2} \mathrm{O}$ concentrations between 500 to $2000 \mathrm{~m}$ depth beneath the iron fertilized waters suggest potential $\mathrm{N}_{2} \mathrm{O}$ production. Rapid sinking of particles would limit $\mathrm{N}_{2} \mathrm{O}$ production in the upper water column and maximize the time period before ventilation. Consequently, the vertical particle export rate is critical to OIF, not just in terms of the efficacy of carbon sequestration and effectiveness, but also with respect to the timeframe to subsequent $\mathrm{N}_{2} \mathrm{O}$ emission. At present, the majority of $\mathrm{N}_{2} \mathrm{O}$ turnover occurs in the upper $300 \mathrm{~m}$ (Codispoti et al. 2001) and so ventilation to the atmosphere will be within a $100 \mathrm{yr}$ timeframe.

\section{LONGER-TERM EFFECTS ON $\mathrm{N}_{2} \mathrm{O}$}

Extrapolations and models provide some insight into the longer-term effects of OIF that defy observational capability. For example, remineralization of the additional carbon fixed during SOIREE was estimated to subsequently produce 2.1 to 4.1 t of $\mathrm{N}_{2} \mathrm{O}$ (Law \& Ling 2001), assuming Redfield stoichiometry and a nitrification: $\mathrm{N}_{2} \mathrm{O}$ production rate of 0.25 to $0.5 \%$ (Goreau et al. 1980). Due to the high GWP of $\mathrm{N}_{2} \mathrm{O}$, this would offset the reduction in radiative forcing achieved through increased carbon fixation by at least 6 to $12 \%$ (Law \& Ling 2001). Initial model estimates of long-term (100 yr) iron fertilization of the Southern Ocean, based on the assumption of complete macronutrient drawdown, suggested that increases in $\mathrm{N}_{2} \mathrm{O}$ production could completely offset the benefit gained by increased carbon fixation (Fuhrman \& Capone 1991, Law \& Ling 2001). More recent analysis of Southern Ocean iron fertilization using 3D models suggests a more conservative offset of 6 to $18 \%$ due to downstream far-field effects, as iron-stimulated macronutrient utilization increases local $\mathrm{N}_{2} \mathrm{O}$ production, but reduces production in the tropics due to decreased macronutrient supply (Jin \& Gruber 2003). However, Jin \& Gruber (2003) identify a more significant $\mathrm{N}_{2} \mathrm{O}$ offset of 37 to $47 \%$ from fertilization of the tropics, increasing to 58 to $194 \%$ when fertilization was limited to 10 yr. The latter arises from the disproportionate effect of long-term decreases in dissolved oxygen and associated $\mathrm{N}_{2} \mathrm{O}$ production relative to a shorter period of $\mathrm{CO}_{2}$ drawdown. These examples illustrate the necessity to consider long-term $\mathrm{N}_{2} \mathrm{O}$ production when determining potential sites and duration of OIF. In particular, for assessment of any future OIF should address the model predictions that (1) small-scale and/or shorter-term fertilization may not reduce $\mathrm{N}_{2} \mathrm{O}$ production and emissions proportionally, (2) cessation of fertilization will not bring $\mathrm{N}_{2} \mathrm{O}$ production back to baseline levels in the short-term, and (3) $\mathrm{N}_{2} \mathrm{O}$ production hotspots may relocate (Jin \& Gruber 2003).

Monitoring of potential adverse effects is a key issue for future OIF, as identified by the recent London Convention (2007) statement, which recommended evaluation of 'potential impacts of gases that may be produced by the expected phytoplankton blooms or by bacteria decomposing the dead phytoplankton' (London Convention 2007, p. 2). This presents a challenge for $\mathrm{N}_{2} \mathrm{O}$, as any perturbation will be small relative to a background signal that exhibits natural spatial variability; for example, $\mathrm{N}_{2} \mathrm{O}$ at $200 \mathrm{~m}$ to $800 \mathrm{~m}$ may exceed $1000 \%$ saturation in upwelling regions (Law \& Owens 1990). In addition, $\mathrm{N}_{2} \mathrm{O}$ will be responsive to climate change as warming of the ocean will decrease oxygen solubility and increase bacterial remineralization (Schmittner et al. 2008), thus complicating attribution of increases in $\mathrm{N}_{2} \mathrm{O}$ to OIF. Current technology limits the capacity for monitoring, as autonomous in situ $\mathrm{N}_{2} \mathrm{O}$ sensors are insufficiently sensitive to measure $\mathrm{N}_{2} \mathrm{O}$ concentrations ( 5 to $30 \mathrm{nmol} \mathrm{l}^{-1}$ ) in the open ocean. Shipboard techniques using electron capture detector gas chromatograph (ECD-GC) provide sufficient sensitivity but limited vertical resolution and areal coverage; they are sufficient for surface mapping of $\mathrm{N}_{2} \mathrm{O}$ distribution, but not for following mid-water $\mathrm{N}_{2} \mathrm{O}$ production and along-isopycnal transport over distances of $1000 \mathrm{~s}$ of $\mathrm{km}$. An alternative approach for monitoring over large spatial and temporal scales is to use $\mathrm{O}_{2}$ concentration as a proxy for $\mathrm{N}_{2} \mathrm{O}$, by utilizing the parameterization for $\mathrm{N}_{2} \mathrm{O}$ as a nonlinear function of $\mathrm{O}_{2}$ and depth (Nevison et al. 2003). $\mathrm{O}_{2}$ optode measurements on Argo floats show considerable promise 
for broad-scale mapping of oxygen in intermediate and deep waters (Roemmich et al. 2004, Riser \& Johnson 2008), and provision of a large pre-fertilization database against which post-OIF changes in oxygen and $\mathrm{N}_{2} \mathrm{O}$ could be assessed. This approach could be augmented using oxygen optodes on gliders for repeat transect measurements and by the use of passive and deliberate tracer distributions on isopycnals for attribution of changes in oxygen and $\mathrm{N}_{2} \mathrm{O}$ to OIF. Use of dissolved $\mathrm{O}_{2}$ as a proxy would require further validation of the $\mathrm{N}_{2} \mathrm{O}-\mathrm{O}_{2}$ relationship and its regional variability. For example, variability may arise from changes in iron availability; iron is a component of ammonium monooxygenase and hydroxylamine oxidase enzymes (Moir et al. 1996, Zahn et al. 1996) and so may influence both nitrification rate and $\mathrm{N}_{2} \mathrm{O}$ yield. In addition, $\mathrm{N}_{2} \mathrm{O}$ yield may be influenced by nitrogen fixation (Nevison et al. 2003), which warrants further investigation as iron availability is a limiting factor for nitrogen fixation in low latitude waters (Mills et al. 2004).

\section{DMS AND OIF}

DMS represents a potential link between the iron and Charlson-Lovelock-Andreae-Warren (CLAW) hypotheses (Charlson et al. 1987, Martin 1990), which have together dominated surface ocean biogeochemical research over the last decade. DMS has a short atmospheric lifetime and may influence climate change via particle formation and alteration of atmospheric albedo. The CLAW hypothesis (Charlson et al. 1987), which invokes oceanic regulation of climate via phytoplankton production of DMS precursors, DMS emission, and aerosol and cloud condensation nuclei (CCN) production that influences atmospheric albedo, still remains to be proven some $20 \mathrm{yr}$ after inception (Harvey 2007). This reflects both its inherent complexity and the logistical difficulty of relating a variety of biogeochemical, physical and photochemical processes occurring at different spatial and temporal scales, as recently summarized in a series of papers in Environmental Chemistry (2007, Vol. 4). Nevertheless, as the DMS precursor dimethylsulphonopropionate (DMSP) is produced by certain phytoplankton groups and initial paleoceanographic evidence indicated a sulphur-iron-climate link (Legrand et al. 1988), the potential for iron-mediated DMS production has been well studied, with DMS measurements on 9 of the 12 FeAXs (Boyd et al. 2007). Initial confirmation was provided by the first 4 FeAXs in the equatorial Pacific and Southern Oceans, which exhibited similar trends of increased production of DMSP followed by DMS increases (1.5- to 6.5-fold) associated with a decline in nanophytoplankton ( 2 to $20 \mu \mathrm{m}$ ) stocks 12 to $14 \mathrm{~d}$ after fertilization (Turner et al. 2004). Consistent with this, a 5-fold increase in DMS was observed during the subsequent Southern Ocean Iron Experiment (SOFeX) campaign and extrapolated regionally to suggest that iron fertilization of the Southern Ocean could potentially double global DMS emissions (14 $\mathrm{Tg} \mathrm{S} \mathrm{yr}^{-1}$, Wingenter et al. 2004). A subsequent more conservative estimate, based upon iron fertilization of $2 \%$ of the Southern Ocean, suggested a $20 \%$ DMS increase that could produce a $2^{\circ} \mathrm{C}$ decrease over the Southern Ocean via the CLAW hypothesis (Wingenter et al. 2007).

However, subsequent FeAXs in the north Pacific exhibited significant departures from the initial experiments (Fig. 1), with no significant change in DMS during SEEDS (Sub-Arctic Pacific Experiment for Ecosystem Dynamics Study) despite the highest response in chlorophyll concentration observed in a FeAX (Takeda \& Tsuda 2005, Boyd et al. 2007). Furthermore, in the most detailed FeAX study of DMS cycling during SERIES, the initial increase in nanophytoplankton stocks and DMSP was instead followed by only a minor increase in DMS, with a subsequent decline to concentrations one order of magnitude lower than surrounding unfertilized waters (Levasseur et al. 2006, Merzouk et al. 2006). Instead of DMS production initiated by herbivory, as in previous FeAXs, increases in bacterial production and associated sulphur demand resulted in DMSP and DMS utilization. This variability in DMS response to iron addition, with Southern Ocean waters representing a significant DMS source and the subarctic Pacific a sink, indicates the need for comparative studies to determine the origin of regional variation. It is also a good illustration of the importance of extrapolating individual FeAX results on a regional basis, rather than to the global ocean. Recent palaeorecord analysis found no co-variation of non-sea salt sulphate, a DMS proxy, with glacial-interglacial variations in dust supply (Wolff et al. 2006). As the role of iron as a major control of DMS has become less certain, other factors such as UV-radiation have been identified as important drivers of DMS seasonality (Vallina \& Simo 2007). Indeed, the potential myriad responses of DMS to the interaction of climate-reactive physical and biogeochemical drivers (Harvey 2007) presents large uncertainty in the prediction of future DMS emissions, even without the confounding influence of OIF.

Monitoring of DMS in the ocean is currently limited to shipboard measurement as autonomous sensors of sufficient sensitivity are not available. However, recent analytical advances include the Membrane Inlet Mass Spectrometer, which has the capacity for sampling dissolved DMS at high spatial resolution (Tortell 2005), and the Atmospheric Pressure Ionization Mass Spectrometer (APIMS), which provides direct measurement 
of atmospheric DMS (Huebert et al. 2004) on both research vessels and aircraft. Verification and attribution of changes in aerosol concentrations and CCN arising from iron-induced DMS production is more challenging. Atmospheric sulphur measurements during SERIES attempted to characterize downwind aerosol composition, but were complicated by the size of the patch relative to the large wind fetch (Phinney et al. 2007). This reflects the difficulty of positioning and scaling shipboard air measurements relative to a small-scale (100 to $500 \mathrm{~km}^{2}$ ) patch, and thus the requirement for rapid and adaptive airborne measurements on timescales of $<24 \mathrm{~h}$. Characterization of seasonal and regional variability in marine DMS and atmospheric sulphur and aerosol composition (Boers et al. 1998) should be a pre-requisite of future OIF. 'Natural laboratories,' such as phytoplankton blooms at open-ocean frontal regions and island wakes, offer potential for studying both DMS cycling and associated aerosol production prior to OIF. Such natural laboratories would be ideally sited in the southern hemisphere, due to the favourably low background aerosol concentration at accessible locations for repeat aircraft sampling.

\section{NET IMPACT OF OIF ON ATMOSPHERIC PROCESSES}

DMS and $\mathrm{N}_{2} \mathrm{O}$ have been used above to illustrate the issues relating to prediction and monitoring of trace gas response to OIF. Other trace gases monitored during FeAXs include carbon monoxide and methane, which decreased and increased, respectively, during SOFeX, and isoprene, which increased 5- to 6-fold during SOFeX and SERIES (Fig. 1) (Wingenter et al. 2004, Moore \& Wang 2006). These trace gases react with hydroxyl radicals in the troposphere, so variation in their marine emission will influence the atmospheric lifetime of other short-lived OH-reactive gases, such as DMS and halocarbons. Consequently, altered emissions of different trace gases could have positive or negative synergistic effects on atmospheric processes. Halocarbons have also exhibited a range of responses in FeAXs (Fig. 1), with positive, negative and negligible responses observed in methyl bromide and methyl iodide concentrations (Wingenter et al. 2004, Liss et al. 2005, Moore \& Wang 2006), potentially reflecting regional variations in photochemistry and plankton community composition. Secondary effects on atmospheric chemistry and climate may also arise from OIF via changes in halocarbon emissions, for example, with increased methyl bromide emissions in the Southern Ocean potentially delaying the recovery of stratospheric ozone (Wingenter et al. 2004). For comprehen- sive monitoring and modeling of OIF, it is then essential to determine the net effect of changes in emissions of different trace gases on atmospheric processes and climatic forcing, with priority on the radiative balance and tropospheric oxidation capacity. This information should then be summarized in a similar manner to the IPCC radiative forcing components (IPCC 2007), an approach that would facilitate assessment of both ironmediated changes on individual trace gases and the net impact on climate and atmospheric composition, and so assist monitoring bodies and policy makers in determining the impacts of ocean iron fertilization.

\section{LITERATURE CITED}

Bange, HW (2006) Nitrous oxide and methane in European coastal waters. Estuar Coast Shelf Sci 70:361-374

Boers R, Jensen JB, Krummel PB (1998) Microphysical and shortwave radiative structure of stratocumulus clouds over the Southern Ocean: summer results and seasonal differences. Q J R Meteorol Soc 124:151-168

Boyd PW, Strzpek R, Takeda S, Jackson G and others (2005) The evolution and termination of an iron-induced mesoscale bloom in the North East subarctic Pacific. Limnol Oceanogr 50(6):1872-1886

Boyd PW, Jickells T, Law CS, Blain S, Boyle E and others (2007) A synthesis of mesoscale iron-enrichment experiments 1993-2005: key findings and implications for ocean biogeochemistry. Science 315:612-617

Chan F, Barth JA, Lubchenco J, Kirincich A, Weeks H, Peterson WT, Menge BA (2008) Evidence of anoxia in the California Current Large Marine Ecosystem. Science 319:920

> Charlson RJ, Lovelock JE, Andreae MO, Warren SG (1987) Oceanic phytoplankton, atmospheric sulfur, cloud albedo and climate. Nature 326:655-661

Codispoti LA, Brandes JA, Christensen JP, Devol AH, Naqvi SWA, Paerl HW, Yoshinari T (2001) The oceanic fixed nitrogen and nitrous oxide budgets: Moving targets as we enter the anthropocene? Sci Mar 65(S2):85-105

Dore JE, Popp BN, Karl DM, Sansone FJ (1998) A large source of atmospheric nitrous oxide from subtropical North Pacific surface waters. Nature 396:63-66

Forster P, Ramaswamy V, Artaxo P, Berntsen T and others (2007). Changes in atmospheric constituents and in radiative forcing. In: Solomon S, Qin D, Manning M, Chen Z and others (eds) Climate change 2007: the physical science basis. Contribution of Working Group I to the fourth assessment report of the Intergovernmental Panel on Climate Change. Cambridge University Press, Cambridge

Fuhrman JA, Capone DG (1991) Possible biogeochemical consequences of ocean fertilization. Limnol Oceanogr 68: 1951-1959

Goreau TJ, Kaplan WA, Wofsy SC, McElroy MB, Valois FW, Watson SW (1980) Production of $\mathrm{NO}_{2}{ }^{-}$and $\mathrm{N}_{2} \mathrm{O}$ by nitrifying bacteria at reduced concentrations of oxygen. Appl Environ Microbiol 40:526-532

Harvey M (2007) The iron CLAW. Environ Chem 4:396-399

Huebert BJ, Blomquist BW, Hare JE, Fairall CW, Johnson JE, Bates TS (2004) Measurement of the sea-air DMS flux and transfer velocity using eddy correlation. Geophys Res Lett 31(23):L23113

IPCC (Intergovernmental Panel on Climate Change) (2007) Summary for policymakers. In: Solomon S, Qin D, Manning M, Chen Z and others (eds) Climate change 2007: the 
physical science basis. Contribution of Working Group I to the fourth assessment report of the Intergovernmental Panel on Climate Change. Cambridge University Press, Cambridge

Jin X, Gruber N (2003) Offsetting the radiative benefit of ocean iron fertilization by enhancing $\mathrm{N}_{2} \mathrm{O}$ emissions. Geophys Res Lett 30(24):2249-2252

Law CS, Ling RD (2001) Nitrous oxide fluxes in the Antarctic Circumpolar Current, and the potential response to increased iron availability. Deep-Sea Res II 48:2509-2528

Law CS, Owens NJP (1990) Significant flux of atmospheric nitrous oxide from the northwest Indian Ocean. Nature 346:826-828

Legrand MR, Delmas RJ, Charlson RJ (1988) Climate forcing implications from Vostok ice-core sulphate data. Nature 334:418

Levasseur M, Scarratt MG, Michaud S, Merzouk A and others (2006) DMSP and DMS dynamics during a mesoscale iron fertilization experiment in the northeast Pacific. I. Temporal and vertical distributions. Deep-Sea Res II 53: 2353-2369

Liss PS, Chuck A, Bakker D, Turner S (2005) Ocean fertilization with iron: effects on climate and air quality. Tellus 57B:269-271

London Convention (2007) Statement of concern regarding iron fertilization of the oceans to sequester $\mathrm{CO}_{2} .13 \mathrm{July}$, 2007. LC-L P1(C):irc14, available at: http://www.imo.org/ includes/blastData.asp/doc_id=8272/14.pdf

Martin JH (1990) Glacial-interglacial $\mathrm{CO}_{2}$ change: the iron hypothesis. Paleoceanography 5:1-13

Merzouk A, Levasseur M, Scarratt MG, Michaud S and others (2006) DMSP and DMS dynamics during a mesoscale iron fertilization experiment in the Northeast Pacific. II. Biological cycling. Deep-Sea Res II 53:2370-2383

Mills MM, Ridame C, Davey M, La Roche J, Geider RJ (2004) Iron and phosphorus co-limit nitrogen fixation in the eastern tropical North Atlantic. Nature 429:292-294

Moir JWB, Wehrfritz JM, Spiro S, Richardson DJ (1996) The biochemical characterization of a novel non-haem-iron hydroxylamine oxidase from Paracoccus denitrificans GB17. Biochem J 319:823-827

Monteiro PMS, van der Plas A, Mohrholz V, Mabille E, Pascall A, Joubert W (2006) Variability of natural hypoxia and methane in a coastal upwelling system: Oceanic physics or shelf biology? Geophys Res Lett 33:L16614

Moore RM, Wang L (2006) The influence of iron fertilization on the fluxes of methyl halides and isoprene from ocean to atmosphere in the SERIES experiment. Deep-Sea Res II 53:2398-2409

Nevison C, Butler JH, Elkins JW (2003) Global distribution of $\mathrm{N}_{2} \mathrm{O}$ and the $\Delta \mathrm{N}_{2} \mathrm{O}-\mathrm{AOU}$ yield in the subsurface ocean. Global Biogeochem Cycles 17(4):1119

Phinney L, Leaitch WR, Lohmann U, Boudries H and others (2007) Characterization of the aerosol over the sub-arctic northeast Pacific Ocean. Deep-Sea Res II 53(20-22): 2410-2433

Popp BN, Westley MB, Toyoda S, Miwa T and others (2002) Nitrogen and oxygen isotopomeric constraints on the origins and sea-to-air flux of $\mathrm{N}_{2} \mathrm{O}$ in the oligotrophic subtropical North Pacific gyre. Global Biogeochem Cycles 16(4):1064

Riser SC, Johnson KS (2008) Net production of oxygen in the subtropical ocean. Nature 451:323-325

Roemmich D, Riser S, Davis R, Desaubies Y (2004) Autonomous profiling floats: workhorse for broad-scale ocean observations. Mar Tech Soc J 38(2):21-29

> Schmittner A, Oschlies A, Matthews HD, Galbraith ED (2008) Future changes in climate, ocean circulation, ecosystems, and biogeochemical cycling simulated for a business-asusual $\mathrm{CO}_{2}$ emission scenario until year $4000 \mathrm{AD}$. Global Biogeochem Cycles 22:GB1013

Takeda S, Tsuda A (2005) An in situ iron-enrichment experiment in the western subarctic Pacific (SEEDS): introduction and summary. Prog Oceanogr 64:95-109

Tortell PD (2005) Small-scale heterogeneity of dissolved gas concentrations in marine continental shelf waters. Geochem Geophys Geosyst 6:Q11M04

Turner SM, Harvey MJ, Law CS, Nightingale PD, Liss PS (2004) Iron-induced changes in oceanic sulfur biogeochemistry. Geophys Res Lett 31:L14307

Vallina SM, Simo R (2007) Re-visiting the CLAW hypothesis. Environ Chem 4:384-387

Walter S, Peeken I, Lochte K, Webb A, Bange HW (2005) Nitrous oxide measurements during EIFEX, the European Iron Fertilization Experiment in the subpolar South Atlantic Ocean. Geophys Res Lett 32, L23613

Wingenter OW, Haase KB, Strutton P, Friederich G, Meinardi S, Blake DR, Rowland FS (2004) Changing concentrations of $\mathrm{CO}, \mathrm{CH}_{4}, \mathrm{C}_{5} \mathrm{H}_{8}, \mathrm{CH}_{3} \mathrm{Br}, \mathrm{CH}_{3} \mathrm{I}$, and dimethyl sulfide during the Southern Ocean Iron Enrichment Experiments. Proc Natl Acad Sci USA 101:8537-8541

Wingenter OW, Elliot SM, Blake DR (2007) New directions: enhancing the natural sulfur cycle to slow global warming. Atmos Environ 41:7373-7375

Wolff EW, Fischer H, Fundel F, Ruth U and others (2006) Southern Ocean sea-ice extent, productivity and iron flux over the past eight glacial cycles. Nature 440:491-496

Wong CS, Timothy DA, Law CS, Nojiri Y, Xie L, Wong SKE, Page JS (2006) Carbon distribution and fluxes during the SERIES iron fertilization experiment with special reference to the fugacity of carbon dioxide $\left(\mathrm{fCO}_{2}\right)$. Deep-Sea Res II 53:2053-2074

Yool A, Martin AP, Fernandez C, Clark DR (2007) The significance of nitrification for oceanic new production. Nature 447:999-1002

> Zahn JA, Arcerio DM, Hooper AB, DiSpirito AA (1996) Evidence for an iron center in the ammonia monooxygenase from Nitrosomonas europaea. FEBS Lett 397:35-38 